\title{
Has Thailand learnt any Lessons from the Bowring Treaty and the Treaty of Amity?
}

\author{
By Nucharee Nuchkoom Smith ${ }^{*} \&$ Robert Brian Smith
}

Thailand signed its first trade treaty with a European power with Portugal in 1516. Treaties with Spain, the Dutch followed. Arguably the two most significant treaties signed by Thailand in historical times were the Bowring Treaty signed with the British in 1855 and the Treaty of Amity and Commerce signed with the United States in 1833 and, following a number of replacements, the current version - the Treaty of Amity and Economic Relations was signed in 1966 and entered into force in 1968 at the height of the Vietnam War. The Bowring Treaty resulted in Thailand ceding its sovereignty over British subjects in Thailand to British law. This treaty lasted for 70 years. The Treaty of Amity originally provided more favourable benefits to United States enterprises than did the British under their earlier treaty of 1826. They were less favourable than those that were negotiated by the British in the Bowring Treaty. Thailand clearly ceded some of its sovereignty under these treaties and then sought to retrieve the situation over the following century. Since 1991 Thailand has been a party to negotiations for 30 Free Trade Agreements (FTAs) with 13 having entered into force. At the same time Thailand has signed 40 Bilateral Investment Treaties of which 37 have entered into force. The paper analyses whether or not Thailand has learnt lessons from the obligations imposed under its past treaties and as a result has it been advantaged or disadvantaged again during its post 1990 treaty obligations.

Keywords: Trade agreements; Sovereignty; Thailand; Bilateral investment treaties; Extraterritoriality

\section{Introduction}

In the past, Thailand, as a trading nation, often allowed trading partners to exercise extraterritoriality in return for concessions in international trade and also to protect its independence as a nation. The outcome was that the laws of foreign powers operated in Thailand in parallel with Thai laws. As will be seen the two most significant treaties were the Bowring Treaty and the Treaty of Amity.

With a strengthening of its legal and bureaucratic processes and practices in the early 1900s Thailand was able to extricate itself from such treaties.

There is still a real danger that, with the growth in international trade that trading partners will seek to impose their laws on Thailand's domestic laws. Often these requirements are in excess of what Thailand has committed to when signing an international treaty covering the same subject matter.

\footnotetext{
${ }^{*} \mathrm{PhD}$, Lecturer, School of Political Science and Laws, Walailak University, Tha Sala District, Nakhon Si Thammarat Province, Thailand. Email: nucharee.sm@wu.ac.th.

${ }^{\ddagger} \mathrm{PhD}$, Academic Advisor, Walailak University, Tha Sala District, Nakhon Si Thammarat Province, Thailand. Email: r.b.smith@unswalumni.com.
} 
This paper analyses whether or not Thailand has learnt lessons from the obligations imposed under its past treaties and as a result has it been advantaged or disadvantaged again during its post 1990 treaty obligations.

The paper will review Thailand's economic development and international trade from an historic perspective as this provides the platform for Thailand's continuing commitment to international trade. This is followed by an analysis of the key extraterritorial conditions of the two most significant treaties: the Bowring Treaty and the Treaty of Amity.

Since Thailand joined the World trade Organization (WTO) in 1995 it has been very active in protecting its interests both, in the WTO, and in negotiations for bilateral and plurilateral free trade agreements. Three case studies are presented. The collected data will then be analysed to see whether Thailand has learned from its previous experiences and has the capability and capacity to defend its national interests.

\section{Historical Background}

Thailand's modern economic development commenced with the foundation of Ayutthaya as its capital in $1351 .^{1}$ At this time, it was a river trading centre where people congregated for trade and worship. Ayutthaya remained the capital for 417 years during which time there were 33 kings and five dynasties - all absolute monarchs.

Thailand has a long history of international trade. The first treaty with a European country was a treaty of friendship and commerce with Portugal in $1516^{2}$ In return for guns and ammunition, the Portuguese were allowed to reside at Ayutthaya and other trading centres where they purchased agricultural products.

The Spanish, from Manila, negotiated a treaty of friendship and commerce in 1598. There was little increase in trade as Spain concentrated its trading interests with other countries. ${ }^{3}$ In 1604 the Dutch were given permission to set up a trading post in Ayutthaya. The Dutch traded their cotton goods for animal hides and pepper. A treaty for the purchase of hides was signed in $1617 .^{4}$ The Japanese came to Ayutthaya as soldiers of fortune, adventurers, sailors and traders and by 1593 there were 500 Japanese soldiers in the Thai army. ${ }^{5}$

The English East India Company arrived in Ayutthaya in 1612 and was granted trading rights and land to build their trading warehouses. The English enterprises at Ayutthaya and Pattani were unprofitable so the company withdrew from Thailand in $1625 .^{6}$

The credit for opening the relations between Thailand and France went to the French Catholic missionaries from the French Foreign Mission. In 1687

\footnotetext{
${ }^{1}$ Syamananda (1993) at 2.

${ }^{2}$ Ibid, at 43.

${ }^{3}$ Ibid. at 61 .

${ }^{4}$ Ibid, at 63 .

${ }^{5}$ Ibid, at 64.

${ }^{6}$ Ibid, at 65.
} 
Thailand signed a commercial treaty with France allowing the French East India Company to trade at Ayutthaya without the payment of duties. Supplies of white saltpetre, black saltpetre, sulphur, firearms and weapons were to be secured from the Thai Government. The company also monopolised the tin business at Thalang Bangclee on Phuket Island. ${ }^{7}$

Most of these ties such as those with England and Spain did not result in long term trade for Thailand. ${ }^{8}$

When John Crawford was sent by the East India Company to negotiate a trade treaty in 1821, trade was a royal monopoly as all goods belonged to the absolute monarchy; taxation and trade were outsourced to Chinese merchants and taxfarmers who applied significant mark-ups. ${ }^{9}$ The Thai government at the time lacked the resources to collect taxes so the government auctioned the monopoly to collect a particular tax in a geographical area for a set period with the 'tax farmer' paying to the government the agreed amount. ${ }^{10}$ Unsurprisingly, the British were unhappy with the price of goods procured by this method and desired a commercial treaty which was more advantageous to them. The negotiations with Crawford broke down because the Thais required arms and ammunition in return for trading facilities and Thailand's insistence on a large sugar sale to Britain.

The United States entered into a treaty of commerce and amity in $1833 .{ }^{11}$

King Rama III (1824 to 1851) had a special interest in commerce. During this period the monarch established very strong trade relations with China. He also allowed Christian Missionaries, especially from the United States to enter Thailand. ${ }^{12}$

On 18 April 1855, Thailand and Britain signed the Bowring Treaty. ${ }^{13}$ The Treaty provided Britain with extraterritorial rights over British citizens, removed all restrictions on trade and fixed very low import and export duties. "From the time of the treaty on, Siam was increasingly integrated into an international order dominated by Western powers. This process led to Siam's transformation into a modern nation-state" 14

With the removal of barriers on trade, the Crown was forced to find new methods of raising revenues through direct taxation and indirect taxes on opium, gambling, alcohols and lotteries. ${ }^{15}$

Between 1850 and 1907 rice exports increased from 5\% to $50 \%$ of the total crop due to an increase in acreage as well as intensifying production (p 46). ${ }^{16}$ Over $80 \%$ of the rice exports went to Thailand's traditional markets of Hong Kong and Singapore. ${ }^{17}$ Rubber, tin and teak were also major exports. There was a sharp

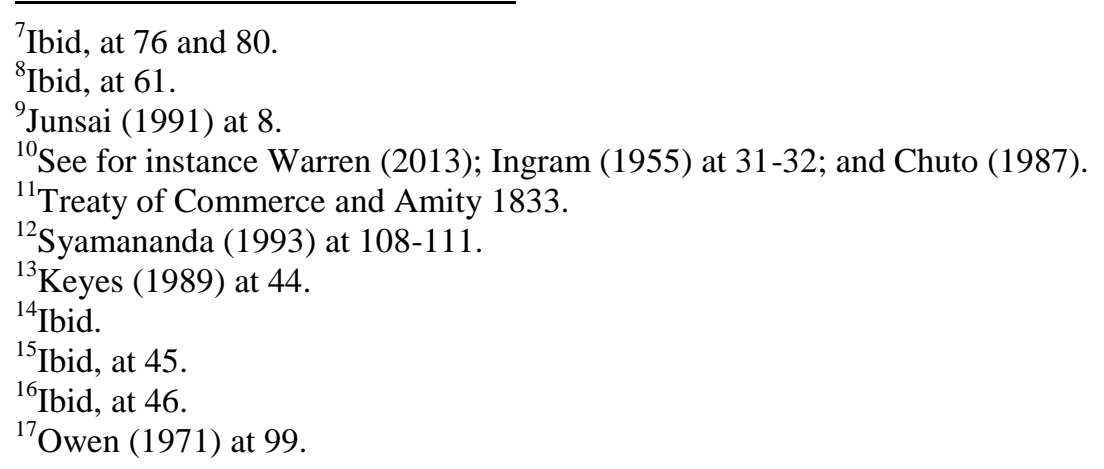


decrease in textile production as cloth and western goods came onto the market. The pattern for modern trade had been established.

Trade led to considerable improvements in infrastructure, particularly in Bangkok. ${ }^{18}$ The new jobs created in Bangkok were overwhelmingly filled by Chinese immigrants who came to Thailand as non-agricultural labourers and traders. This was similar to other societies of countries in Southeast Asia as Thailand was becoming part of an international economic system, but "in other fundamental ways it evolved differently because, unlike those other societies, it was transformed politically by the indigenous elite rather than by Western colonial rulers". 19

The Bowring Treaty was in effect for 70 years and was withdrawn under the reign of King Rama VI in $1925 .^{20}$ The government lost focus on the importance of maintaining its international relationships and trading partners due to its weakened financial situation as the result of excessive infrastructure spending as well as extravagant spending by the monarch. ${ }^{21}$

Keyes, writing in 1989, considers that:

"Thailand's relations with foreign countries have, since the Bowring Treaty [...] been shaped by two major concerns: the integrity of the nation-state and the development of international trade. These concerns have always led Thailand to orient itself toward those powers that were felt more likely to ensure the country's security and to provide markets for Thai products and sources for those goods Thailand wished to import." $22^{2}$

Little has changed since Keyes comment. Thailand's current concerns are still integrity of its borders and international trade. Thailand has an ongoing border dispute with Cambodia particularly the Temple of Preah Vihear, in Khmer, or Prasat Phra Wihan, in Thai, where there are periodic military skirmishes. ${ }^{23}$

\section{Methodology}

As has been seen Thailand has been participating in international trade for centuries often granting extraterritoriality in exchange for trading concessions. It could be argued that this was a result of lack of capacity and negotiating acumen on the part of the Thais. Alternatively, it could be seen as the Thai's willingness to lose some legal oversight of foreign nationals in return for profits that could be obtained by being more competitive and hence more profitable in international commerce.

\footnotetext{
${ }^{18}$ Keyes (1989) at 48.

${ }^{19}$ Ibid.

${ }^{20}$ Syamananda (1993) at 158 .

${ }^{21}$ Paitoonpong \& Abe (2014) at 4.

${ }^{22}$ Keyes (1989) at 111-112.

${ }^{23}$ See for instance: Sothirak (2013); Burgess (2015) at 193-226.
} 
The research uses the narrative/case study approach to examine the lessons that can be learned from the past. It then focuses on three case studies from post-1995 to the present to see whether the lessons have indeed been learned.

\section{Findings - The Era of Extraterritoriality in Treaties with Foreign Powers}

\section{Bowring Treaty}

The Treaty of Friendship and Commerce between Siam and Great Britain ${ }^{24}$ was signed at Bangkok on 18 April 1855.

The interests of British subjects entering Siam were placed under the "regulation and control" of a [British] Consul who would reside in Bangkok. ${ }^{25}$ The role of the Consul was to abide by all of the provisions of the Treaty and enforce its observance by British subjects. This included abiding by all rules and regulations enacted for the "government of British subjects in Siam, the conduct of their trade, and for the prevention of violation of the laws of Siam". Disputes between Siamese and British subjects were to be "heard and determined by the Consul in conjunction with the proper Siamese officers". Punishment of British subjects was to be determined by the Consul in accordance with British laws; punishment of Siamese subjects was to be determined by Siamese officers in accordance with Siamese law. The Consul was not to interfere in matters referring solely to Siamese nor do the Siamese interfere in questions which only concern British subjects.

Whilst British subjects were "permitted to trade freely in all the seaports of Siam" they were required to only reside in Bangkok or its environs (art IV). ${ }^{26}$ They were able to rent land and build houses but were unable to buy land until they had been in Bangkok for 10 years. They were however able to buy or rent houses, lands or plantations within 24 hours of Bangkok "computed by the rate at which boats of the country can travel". The Consul would assist the possession process including the negotiation of the terms of rental or purchase. The property would be placed under the protection of the district authorities and the British subject would be subject to the same taxation regime as the Siamese. If cultivation or improvement of the land had not commenced within three years, the land was to be resumed by the local authorities and the original purchase price returned.

Import duties were set at 3\% of the value of imported goods; payable in either kind or money at the option of the importer. ${ }^{27}$ If the value of the goods was disputed, the Consul and the relevant Siamese official with an equal number of up to two merchants appointed as assessors by each.

Whilst opium was imported free of duty it could only be sold to an opium "farmer"; otherwise it would be confiscated. ${ }^{28}$

\footnotetext{
${ }^{24}$ Better known as the Bowring Treaty.

${ }^{25}$ Bowring Treaty 1855 art II.

${ }^{26}$ Ibid, art IV.

${ }^{27}$ Ibid, art VIII.

${ }^{28}$ Ibid.
} 
Export tariffs were specified in a schedule to the treaty and were the same as those that applied to Siamese or Chinese vessels or junks and any further privileges applied to the Siamese and Chinese vessels would also apply to the British. The British merchants were able to carry out transactions directly with producers or purchasers without interference. Bullion and personal effects were allowed to be imported or exported free of duty.

If there was a scarcity of fish, rice or salt, the government of Siam reserved the right by public proclamation to prohibit the export of these items.

Finally, any privileges that may have been applied or might be granted by the Government of Siam to the Government or subjects of any other nation were to apply to the British Government and its subjects. ${ }^{29}$

\section{Treaty of Amity and Commerce between Siam and the United States, 1833}

The Treaty of Commerce and Amity was signed in Bangkok on 10 March 1833. Citizens from the United States were free to enter all ports in Siam and trade by buying and selling "on the terms and for the prices that the owners may see fit". ${ }^{30}$ Munitions of war could only be sold to the King and opium was considered as contraband. The export of rice was prohibited.

In lieu of import and export duties, license fees or any other charges a measurement duty was imposed. ${ }^{31}$ The duty was calculated on the breadth of the ship. If duties payable for foreign vessels were reduced in favour of any other nation the same would be applied to the vessels of the United States. ${ }^{32}$

If United States citizens coming to Siam for the purposes of trade entered into a debt with a local individual or a local owed a debt to a United States citizen, the debtor was obliged to sell all his goods to pay his debts. If the return from the sale of the goods was insufficient to satisfy the debt the remainder of the debt was forgiven without further punishment. ${ }^{33}$

Merchants wishing to rent houses were required to rent factories [warehouses] owned by the King and pay the customary rent. ${ }^{34}$ If goods were brought on shore no duty was to be levied.

The merchants of the United States were required to respect and follow the laws and customs of Siam "in all points". 35

Finally, if a foreign nation other than Portugal [which already had a Consul in Siam] was given permission to post a resident Consul to Siam then the United States had the liberty to do the same. ${ }^{36}$

\footnotetext{
${ }^{29}$ Ibid, art X.

${ }^{30}$ Treaty of Amity art II.

${ }^{31}$ Ibid art III.

${ }^{32}$ Ibid art IV.

${ }^{33}$ Ibid art VI

${ }^{34}$ Ibid art VII

${ }^{35}$ Ibid art IX.

${ }^{36}$ Ibid art X.
} 
Thailand Revises the Treaties with Foreign Countries 1919 - 1926

In the late 1800s Thailand reorganised its administration and eradicated the need for extraterritoriality. ${ }^{37}$ Extraterritorial rights imposed two obstacles in the eyes of the Siamese, namely consular jurisdiction and the fixing of duties. The earlier treaties permitted amendment but not renouncement, so negotiations took many years. The new treaties contained two main points: consular jurisdiction was terminated with foreign nationals coming under the jurisdiction of Thai courts and Thailand was free to set its own tariffs.

The Bowring Treaty was superseded by the General Treaty of Friendship with Great Britain, 1925 and the Treaty of Commerce and Navigation with the Great Britain, 1925.

The Treaty of Amity and Commerce was superseded by the Treaty of Friendship, Commerce and Navigation with the United States, 1920. During the height of the Vietnam War Thailand and the United States entered into a new treaty.

\section{U.S. - Thailand Treaty of Amity and Economic Relations, 1966}

The Treaty of Amity and Economic Relations between the Kingdom of Thailand and the United States of America was signed at Bangkok on 29 May 1966.

The Treaty allowed nationals of either party to enter the territory of the other party to carry out trade or develop or direct the operations of an enterprise in which they have invested ${ }^{38}$ and have the full protection of the law of that party $(\operatorname{art} \mathrm{I}(2))^{39}$. In most activities the concept of national treatment applied in that they were have the same privileges as the nationals in whose country they were operating. ${ }^{40}$ Parties were prohibited or restricted in participating in enterprises involved in "communications, transport, fiduciary functions, banking involving depository functions, the exploitation of land, or other natural resources, or domestic trade in indigenous agricultural products". ${ }^{41}$ In addition, the parties reserved the right to grant special privileges: to the products of its national fisheries; adjacent countries in order to encourage border trade; and, members of a customs union or free trade area to which it may become a member. ${ }^{42}$ State-owned enterprises from each party were to make their sales and purchases to the other party based on commercial considerations; nationals, companies and commerce of such other party shall have equal opportunity to compete. ${ }^{43}$ Import and export controls could be placed trade in gold or silver: fissionable materials;

\footnotetext{
${ }^{37}$ Ministry of Foreign Affairs 2015.

${ }^{38}$ Treaty of Amity and Economic Relations, 1966 art I (1).

${ }^{39}$ Ibid art I(2)

${ }^{40}$ Ibid. For instance art II, art III, art IV and art V.

${ }^{41}$ Ibid art IV(2).

${ }^{42}$ Ibid art VIII(6).

${ }^{43}$ Ibid art XI(1).
} 
Vol. 5, No. $4 \quad$ Smith \& Smith: Has Thailand learnt any Lessons from the Bowring...

arms, ammunition and implements of war. ${ }^{44}$ Finally, disputes between the parties were to be settled by arbitration. ${ }^{45}$

\section{Thailand since 1995}

Since around 1995, the year Thailand joined the World Trade Organization (WTO) as a founding member, Thailand has become very proactive in both protecting and furthering its interests in the international arena. Three case studies which follow show Thailand's capacity and capability albeit that there have been some miscalculations on the way.

\section{Free \& Fair Trade}

Thailand has been active in protecting its economic interests from that time. As on 1 August 2019, for instance, Thailand was a party to 14 WTO disputes as complainant, four as respondent and 93 as a third party. ${ }^{46}$ All four complaints against Thailand were in relation to violation of the anti-dumping provisions of Art VI of the General Agreement on Tariffs and Trade 1994. Thailand was also a party as complainant in anti-dumping cases.

\section{Poland versus Thailand}

Poland lodged a complaint against Thailand's application of antidumping measures in relation to steel products from Poland. ${ }^{47}$ The Panel and Appellant Body found that Thailand's application of antidumping provisions was inconsistent with the Agreement on Implementation of Article VI of the General Agreement on Tariffs and Trade 1994. Thailand had not evaluated all of the fifteen factors listed in Art 3.4 of the Agreement to determine the impact of the dumped imports on the domestic industry.

\section{Thailand and others versus the United States}

At the end of 2000, Thailand together with Australia, Brazil, Chile, European Communities, India, Indonesia, Japan, and Korea lodged a complaint against United States' application of the Continued Dumping and Subsidy Offset Act of $2000 .^{48}$ The Panel and Appellant Body found that the Act was inconsistent with the Agreement, but the matter finally went to arbitration and the USA was given 11 months to conform. After further negotiation Australia, Indonesia and Thailand agreed to allow the USA a further 12 months to conform. Eventually on 8 February 2008 the USA passed into Law the Deficit Reduction Act which was claimed to bring the USA in full conformity with its WTO obligations. The

\footnotetext{
${ }^{44}$ Ibid art XII(1).

${ }^{45}$ Ibid art XIII(2).

${ }^{46}$ World Trade Organization 2019.

${ }^{47}$ World Trade Organization 2010a.

${ }^{48}$ World Trade Organization (2018).
} 
complainants welcomed the legislation but did not consider that the changes were fully in conformity with the Agreement.

\section{Thailand versus the United States}

Thailand lodged a complaint against the action involving USA's application of antidumping measures on frozen warm-water prawn/shrimp from Thailand. ${ }^{49}$ The Panel and Appellant Body found that the actions of the USA were inconsistent with the Agreement and Thailand allowed the USA time to comply. Thailand also lodged a complaint against the USA's application of anti-dumping measures on Polyethylene Retail Carrier Bags from Thailand. The Panel and Appellant Body found that the actions of the USA were inconsistent with the Agreement on Implementation of Article VI. Again, Thailand allowed the USA time to comply.

\section{Summary}

These cases show that Thailand is capable of defending its exporters against the USA's application of anti-dumping laws that are inconsistent with the Agreement. In addition, Thailand as an active participant in the operations of the WTO is regularly reserving its rights to Dispute Settlement proceedings where the application of any decision to parties other than those in dispute may impinge on its economy.

\section{Trade Negotiations}

Thailand has successfully negotiated nine free trade agreements. ${ }^{50}$ Of these eight are bilateral with the ninth being that with the other nine members of Association of South East Asian Nations (ASEAN). It is in the process of negotiations for another eight bilateral or multilateral agreements. In addition, as member of ASEAN, Thailand is a party to an additional six multilateral free trade agreements. Finally, as part of the sixteen-member ASEAN+6 Group it is negotiating the Regional Comprehensive Economic Partnership, or RCEP.

This is quite an impressive record for a developing country.

Thailand is also willing to stand up to its trading partners and say "No deal" when it considered that an agreement would be contrary to its interests. Such was the case when it was asked by the United States to be part of the negotiations for the Trans Pacific Partnership (TPP).

Whilst advocates saw benefits in becoming part of the push for regional economic integration the opponents were very concerned about the potential adverse effects on Thailand of tighter rules on intellectual property rights and patent registration as well as the potential loss of sovereignty. ${ }^{51}$

In the end, the Government's severe reservations about the advantages of joining resulted in it declining to enter the negotiations. This was partly driven

\footnotetext{
${ }^{49}$ World Trade Organization (2010b).

${ }^{50}$ Asian Development Bank (2019).

${ }^{51}$ Yoon (2012).
} 
by domestic political factors and higher prices for drugs and pharmaceuticals. ${ }^{52}$ There were also concerns about the potential impact on Thailand of enhanced labour and environmental requirements as well as liberalizing the services sector. Another major factor may have been the rule that "nothing is agreed until everything is agreed" which requires the parties to accept all of the TPP clauses. ${ }^{53}$ The final TPP agreement has a significant number of caveats and party to party agreements. ${ }^{54}$ In the end it is likely that Thailand did not join the negotiations because of the delay caused by the continuing distraction of the political crisis. When Thailand had decided the TPP might be a good idea it was too late. ${ }^{55}$ If Thailand had joined the negotiations it could have used its participation to drive a proposal and bargain in some sensitive issues that are current concerns. On the withdrawal of the United States the other eleven TPP signatories negotiated the Comprehensive and Progressive Agreement for Trans-Pacific Partnership ${ }^{56}$ which uses the TPP as its basis but with some of the most contentious clauses removed and subject to further negotiation. The final outcome justifies the opinion of the first author that Thailand should have been part of the original negotiations and would have been able to influence the outcome especially with the help of the ASEAN countries who were part of the TPP negotiations. ${ }^{57}$

\section{Discussion}

Since the time of Thailand's early treaties there has been a drastic change in the way conflicts between countries have been resolved. The use or armed force has given way to negotiation. At the same time a rules-based international trading system has developed under the World Trade Organization.

This has allowed a relatively small country like Thailand to use the international trading rules to defend its industries against unfair actions of others. As described earlier this has allowed Thailand and others to take on the largest international economy, the United States, in the WTO and win. This

\footnotetext{
${ }^{52}$ Limsamarnphum (2015).

${ }^{53}$ This was the common understanding of parliamentary officials with whom the first author was working at the time.

${ }^{54}$ Trans Pacific Partnership Agreement between the Government of Australia and the Governments of: Brunei Darussalam, Canada, Chile, Japan, Malaysia, Mexico, New Zealand, Peru, Singapore, the United States of America and Vietnam signed 4 February 2016 (not yet in force) [2016] ATNIF 2.

${ }^{55}$ The dangers of not being part of the negotiations early can be summed up by reference to Canada. Canada in 2005 rejected the opportunity to join preliminary discussions. When Canada wished to join the negotiations, its prospective partners were required to determine Canada's suitability to join negotiations already in progress. At least two parties, USA and New Zealand had at the time, trade issues with Canada. New Zealand was opposed to Canada's attempts to maintain existing dairy supply management. In 2010, USA officials declined to support Canada's case. They were finally accepted as parties in 2012 (Dawson (2012)).

${ }^{56}$ Comprehensive and Progressive Agreement for Trans-Pacific Partnership signed 8 March 2018 (entered into force 30 December 2018).

${ }^{57}$ Smith (2015).
} 
resulted in the withdrawal of the United States Continued Dumping and Subsidy Offset Act of 2000.

Of course, Thailand's action is not always successful as was the case in its first Investor State Dispute Settlement arbitration defence against Walter Bau. Initially Thailand considered that international arbitration was a threat to its sovereignty. However, following the debacle surrounding the Walter Bau Investor State Dispute Settlement (ISDS) case where Thailand tried, but failed, to overturn the arbitration finding it has realised that arbitration of ISDS disputes is not necessarily the threat that was originally perceived. ${ }^{58}$

As noted by Smith and Smith an Australian mining company gave notice that it was preparing to commence arbitration proceedings against the Thai government over closure of its gold mine under the ISDS provisions of the Thailand-Australia Free Trade Agreement 2005. ${ }^{59}$

Rather than fight the case in the court of public opinion as happened in the Walter Bau case the response was measured. The government announced it had appointed a multi-agency committee to negotiate a settlement in the country's best interests and taking all stakeholders' interests into account. ${ }^{60}$ Most importantly he advised that the government was prepared to settle the dispute under the international arbitration process as sought by Kingsgate. He acknowledged that the process was in accordance with the bi-lateral agreement with Australia. ${ }^{61}$

A small nation like Thailand is no longer frightened of the armed power of powerful countries as it was in the past. As the world has changed these powerful countries, under pressure from the smaller nations, also changed their focus from armed force to negotiation. Nonetheless the powerful still use strategies such as blockades and imposing more stringent international rules to seek advantages over their trading partners.

Thailand has to be vigilant and not fall into such traps. Rather it must use the new rules to protect its sovereignty and economy as best it can.

\section{Conclusions}

Thailand has clearly learned from the past. Up until the early $20^{\text {th }}$ Century Thailand was willing to trade land with France or allow the British extraterritoriality for what it saw as the major benefit - the preservation of its sovereignty.

Times have changed, and Thailand no longer has to make such trade-offs. Rather it uses the rule-based trading system to actively promote and protect its political and economic interests.

\footnotetext{
${ }^{58}$ Smith \& Smith (2018).

${ }^{59}$ Ibid, at 287.

${ }^{60}$ Nation (2017).

${ }^{61}$ That is the Thailand Australia Free Trade Agreement (TAFTA).
} 


\section{References}

Asian Development Bank (2019). Free Trade Agreements. At https://aric.adb.org/databa $\mathrm{se} / \mathrm{fta}$

Burgess, J. (2015). Temple in the Clouds: Faith and Conflict at Preah Vihear. Bangkok: River Books.

Chuto, S. (1987). Government and Politics of Thailand. London: Oxford University Press.

Dawson, L.R. (2012). 'Can Canada Join the Trans-Pacific Partnership? Why just wanting it is not enough'. Commentary No. 340, C.D. Howe Institute, Feb 2012 1-9. At http:// ssrn.com/abstract $=2023963$.

Ingram, J. (1955). Economic Change in Thailand since 1850. Stanford: Stanford University Press.

Jumsai, M. (1991). King Mongkut \& the British, $3^{\text {rd }}$ ed. Bangkok: Chalermait.

Keyes, C. (1989). Thailand: Buddhist Kingdom as Modern Nation-State. Bangkok: Editions Duang Kamol.

Limsamarnphun, N. (2015). 'Thailand Needs to Join TPP, RCEP and Find Right Balance'. The Nation (online), 4 November 2015. At http://www.nationmultimedia.com/po litics/Thailand-needs-to-join-TPP-RCEP-and-fine-right-bal-30272205.html

Ministry of Foreign Affairs of the Kingdom of Thailand (2015.) The Elimination of Extraterritoriality. http://www.mfa.go.th/main/en/organize/1085/19297-TheElimination-of-Extraterritoriality.html.

Nation (2017). Thailand faces uphill fight over gold mine closure. The Nation (online, November 4, 2017). http://www.nationmultimedia.com/detail/national/30330764.

Owen, N. (1971). 'The Rice Industry of Mainland South-east Asia', in Journal of the Siam Society, 59(2):75-143.

Paitoonpong, S. \& S. Abe (2004). 'The Thai Economy: A Picture from the Past', in TDRI Quarterly Review, 19(4):3-12.

Smith, N.N. (2015). 'New Regional Economic Partnerships under Negotiation', in Int. J. Public Law and Policy, 5(1):1-19.

Smith, R.B. \& N.N. Smith (2018). 'Bilateral Investment Treaties - a Potential Trap for Developing Economies: A Lesson from Thailand' in Athens Journal of Business \& Economics 4(3):279-291. doi=10.30958/ajbe.4-3-3.

Sothirak, P. (2013). 'Cambodia's Border Conflict with Thailand' in Southeast Asian Affairs, 87-100.

Syamananda, R. (1993). A History of Thailand. Bangkok: Chulalongkorn University.

Warren, J. (2013). Gambling. The State and Society in Thailand, c. 1800-1945. London and New York: Routledge.

World Trade Organization (2010a). Dispute DS122: Thailand - Anti-Dumping Duties on Angles, Shapes and Sections of Iron or Non-Alloy Steel and H Beams from Poland: Summary to Date (24 February 2010). At http://www.wto.org/english/tra top_e/dis pu_e/cases_e/ds122_e.htm

World Trade Organization (2010 b). Dispute DS324: United States - Provisional AntiDumping Measures on Shrimp from Thailand: Summary to Date (24 February 2010). http://www.wto.org/english/tratop_e/dispu_e/cases_e/ds324_e.htm

World Trade Organization (2010c), Dispute DS343: United States- Measures Relating to Shrimp from Thailand: Summary to Date (24 February 2010). http://www.wto.org/ english/tratop_e/dispu_e/cases_e/ds343_e.htm

World Trade Organization, (2010d). Dispute DS383: United States - Provisional AntiDumping Measures on Shrimp from Thailand: Summary to Date (24 February 2010). http://www.wto.org/english/tratop_e/dispu_e/cases_e/ds383_e.htm 
World Trade Organization (2018). Dispute DS217: United States - Continued Dumping and Subsidy Offset Act of 2000: Summary to Date (27 November 2018). http:// www.wto.org/english/tratop_e/dispu_e/cases_e/ds217_e.htm

World Trade Organization (2019). Dispute Settlement: The Disputes: Disputes by Member. https://www.wto.org/english/tratop_e/dispu_e/dispu_by_country_e.htm

Yoon, S. (2012). 'TPP vs. RCEP: A new Washington-Beijing tug-of-war?' in the Nation (online), 6 December 2012. At http://www.nationmultimedia.com/opi nion/TPP-vsRCEP-A-new-Washington-Beijing-tug-of-war-30195647.html

\title{
Agreements and Treaties
}

Agreement on Implementation of Article VI of the General Agreement on Tariffs and Trade 1994, signed 15 April 1994 (entered into force 1 January 1995).

Comprehensive and Progressive Agreement for Trans-Pacific Partnership signed 8 March 2018 (entered into force 30 December 2018).

General Agreement on Tariffs and Trade (GATT 1994), signed 15 April 1994 (entered into force 1 January 1995).

General Treaty of Friendship with Great Britain, 1925.

Thailand-Australia Free Trade Agreement signed 5 July 2004 (entered into force 1 January 2005) [2005] ATS 2 (TAFTA).

Trans Pacific Partnership Agreement between the Government of Australia and the Governments of: Brunei Darussalam, Canada, Chile, Japan, Malaysia, Mexico, New Zealand, Peru, Singapore, the United States of America and Vietnam signed 4 February 2016 (not yet in force) [2016] ATNIF 2.

Treaty of Amity and Commerce signed on 10 March 1833.

Treaty of Amity and Economic Relations between the Kingdom of Thailand and the United States of America signed 29 May 1966.

Treaty of Commerce and Navigation with the Great Britain, 1925.

Treaty of Friendship, Commerce and Navigation with the United States, 1920.

\author{
Acts \\ Continued Dumping and Subsidy Offset Act (CDSOA), 2000. \\ Deficit Reduction Act, 42 USC, 2006. \\ Thailand-Australia Free Trade Agreement, 2005
}


